\title{
Analysis of the Legal State of Ground Communities ${ }^{3}$
}

Summary: There are over 5,000 land communities in Poland that own real estate with an area of over 100,000 hectares. In 2009, the Supreme Audit Office (SAO, in Polish the Najwyższa Izba Kontroli) carried out an audit of the factual and legal status of State Treasury property and municipal property. The inspection also included properties belonging to land communities and showed numerous irregularities in their functioning throughout Poland. The result of the audit was large changes to the Law regulating the operation of land communities, i.e. the Law of June 29, 1963 on the Development of Land Communities. The amended act was intended to facilitate the regulation of the legal status of many properties in Poland.

This article presents an analysis of the legal status of real estate of land communities made on the basis of the audit carried out in 2009 by the Supreme Audit Office. The article presents the procedure of regulating the legal status of real estate according to the provisions of the amended Law on the management of land communities. Furthermore, it contains the analysis of administrative proceedings concerning land community in selected counties located in the Masovian Voivodeship (i.e. the district of Ostrołęka and the district of Przysucha) to check whether the amended law helped to regulate the legal status of community lands and land communities.

Keywords: land communities, regulation of the legal status

Received: 4 March 2019; accepted: 30 September 2019

(C) 2020 Authors. This is an open access publication, which can be used, distributed and reproduced in any medium according to the Creative Commons CC-BY 4.0 License.

1 AGH University of Science and Technology, Faculty of Mining Surveying and Environmental Engineering, Krakow, Poland, email: akwart@agh.edu.pl ORCID ID: https://orcid.org/0000-0002-7891-2988

2 AGH University of Science and Technology, Faculty of Mining Surveying and Environmental Engineering, Krakow, Poland, email: maczynska@agh.edu.pl

ORCID ID: https://orcid.org/0000-0001-7632-5264

3 The article was prepared under the research subvention of AGH University of Science and Technology No. 16.16.150.545 in 2019 


\section{Introduction}

The beginnings of land communities in Poland date back to the $19^{\text {th }}$ century [1-4]. There is no specific definition of the land community in Polish legislation [5, 6]. The Polish PWN dictionary [7] defines a land community as a right to land constituting the joint ownership of all or part of the inhabitants of a given village. As [5] emphasizes, land communities are a special type of joint ownership with a complex legal nature. According to [8], land communities are a set of specific property rights assigned to real estate. However according to [9], communities of land are certain communities in which collective ownership is the basis of the economy. On the other hand, P. Gołos [3] believes that a community of land is not only common property, but also a common origin, traditions and values. In the legal sense, land communities should be understood from the objective and not the subjective side, because the community is formed by land, not their owners [10]. The essence of land communities is the possibility of using the common ground by the inhabitants of a given area, simply because they are its inhabitants $[2,11]$. Therefore, the community of land should be considered as land that may be used by a specific group of people [2].

The manner of using the community land is conditioned by rights in rem, which are assigned to the land, i.e. ownership or use. The land communities are managed by legal persons established for this purpose in the form of a company for the development of land communities [2, 8]. Legal management of joint land in the form of a company has been reluctantly accepted by municipal land entities [12], therefore it is now possible to liquidate a land management company. The community management company can be transformed into joint ownership in fractional parts. Joint ownership in fractional parts should be entered in the land and mortgage register.

The rules for the functioning of land communities are specified in the Law of June 29, 1963 on the Development of Land Communities [13]. In 2009, the Supreme Audit Office (NIK) carried out an audit of the factual and legal status of the State Treasury property (understood as state property) and municipal property (understood as ownership of local government units) [14]. The inspection also included properties belonging to land communities and showed numerous irregularities in their functioning throughout Poland. The result of the audit was large changes to the act regulating the operation of land communities, i.e. the Law of June 29, 1963 on the Development of Land Communities. The amended law on the development of land communities [13] was to facilitate the regulation of the legal status of many properties in Poland. A property with an unsettled legal status means a property for which, due to the absence of a land register, a collection of documents or other documents, it is impossible to determine people who are entitled to property rights [15]. In the case of land communities, unregulated legal status occurs when a list of those entitled to participate in the community is unknown. The amended Law [13] made it possible to re-determine which properties constitute a community of land, as well as to establish a list of persons entitled to participate in these communities. In the 
event that it is impossible to establish a list of those entitled to participate in the community of land (unregulated legal status of real estate), thanks to the amended law it is possible to take over land belonging to land communities free of charge to the property of the locally competent commune (a local government unit) or the State Treasury (a legal person representing the state). Land takeovers can only be made for public purposes (e.g. construction of public roads). By taking over land that the owner is not known to the municipality or state, it is possible to regulate the legal status of such land.

At the beginning, this article presents results of the analysis of the legal status of real estate of land community made by of the Supreme Audit Office in 2009. The results of the analysis were presented to show the size of the problem of unregulated land in Poland. Next, due to the possibility of regulating the legal status of community lands introduced by the amended Law, the article analyzes the applicable legal regulations. On this basis, the article presents the procedure of regulating the legal status of real estate according to the provisions of the amended Law. Furthermore, to check whether the amended law helped regulate the legal status of community lands, an analysis of administrative proceedings concerning land community in selected counties located in the Masovian Voivodeship (i.e. the district of Ostrołęka and the district of Przysucha) was made.

\section{Analysis of the Legal Status of Real Estate of Land Communities Based on the SAO Data}

There are over 5,000 land communities in Poland. They have real estate with an area of over 100,000 hectares [14]. We distinguish the following communities: agricultural, forest, water and mixed (e.g. agricultural - forest) [14]. The largest number are mixed communities $-2,214$, which accounts for $43 \%$ of the total number of all land communities (Fig. 1). The least are water communities -79 , which accounts for $2 \%$ of the total number of all land communities. The largest area of community lands is forest land $-47,994$ ha, which is $44 \%$ of the total area of land communities (Fig. 2). The smallest area of community lands is water land $-1,143 \mathrm{ha}$, which is $1 \%$ of the total area of land communities.

According to Table 1, the largest area of real estate owned by land communities is in the Masovian (20,714.11 ha) and Lublin voivodeships (23,226.06 ha), the smallest in Opole Voivodeship (37.71 ha). In three voivodeships located along the western Polish border: dolnośląskie, lubuskie, and zachodniopomorskie, land communities are absent (Tab. 1, Fig. 3).

Figure 3 presents the areas of individual type land (agricultural, forestry, water, rest) for the land of land communities broken down into voivodships along with the total area of land of the communities. According to Figure 3, the largest area has communities of agricultural and communities of forestry. 


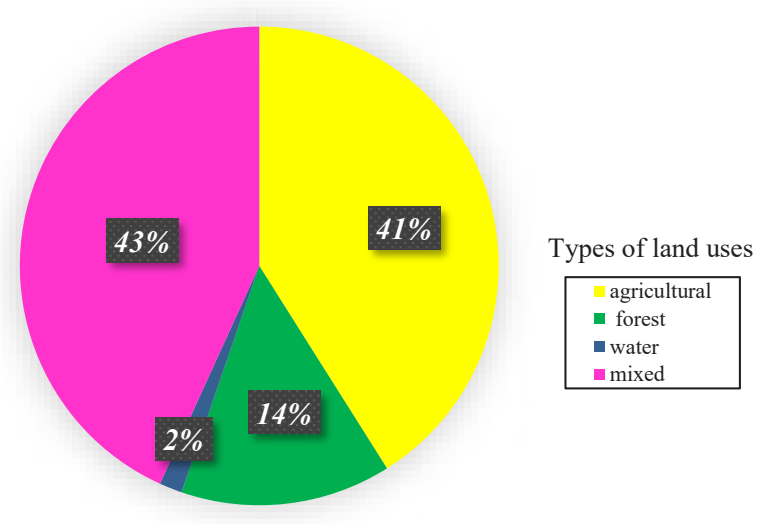

Fig. 1. Types (land uses) of land communities in Poland

Source: own work based on the [14]

In accordance with applicable regulations law [13], for the management and management of community lands, persons entitled to participate in the community of land should establish a company (type of contract in Polish law). However, the very establishment of the company is not enough to act on its behalf [16]. It is necessary to pass the statute of company. Pursuant to the amended act [13], the company acquires legal personality only at the moment when the starosta (the public administration managing the county) decision approving the company's statute becomes final, so in order to properly manage the property of the community, it is necessary to establish a company whose statute is approved by the starosta.

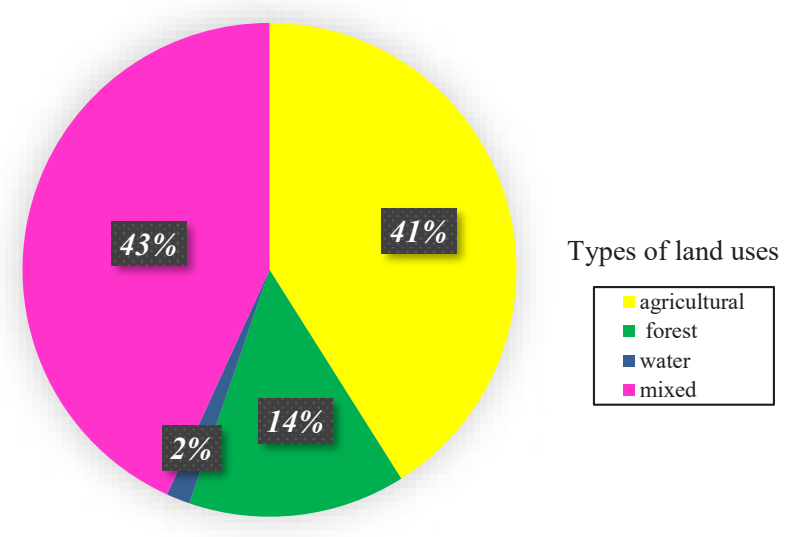

Fig. 2. Area of land communities divided into types of them Source: own work based on [14] 
Table 1. Area of land communities in different voivodeships

\begin{tabular}{||c|c|c|}
\hline No. & Voivodship (administrative division in Poland) & Area [ha] \\
\hline \hline 1 & kujawsko-pomorskie (Kuyavian-Pomeranian Voivodeship) & 884.98 \\
\hline 2 & lubelskie (Lublin Voivodeship) & $23,226.06$ \\
\hline 3 & lódzkie (Łódź Voivodeship) & $11,655.44$ \\
\hline 4 & małopolskie (Lesser Poland Voivodeship) & $13,934.31$ \\
\hline 5 & mazowieckie (Masovian Voivodeship) & $20,714.11$ \\
\hline 6 & opolskie (Opole Voivodeship) & 37.71 \\
\hline 7 & podkarpackie (Subcarpathian Voivodeship) & $7,516,36$ \\
\hline 8 & podlaskie (Podlachian Voivodeship) & $11,126.55$ \\
\hline 9 & pomorskie (Pomeranian Voivodeship) & 122.73 \\
\hline 10 & śląskie (Silesian Voivodeship) & $6,792.41$ \\
\hline 11 & świętokrzyskie (Świętokrzyskie Voivodeship) & $8,671.02$ \\
\hline 12 & warmińsko-mazurskie (Warmian-Masurian Voivodeship) & 235.05 \\
\hline 13 & wielkopolskie (Greater Poland Voivodeship) & $2,705.89$ \\
\hline 14 & dolnośląskie (Lower Silesian Voivodeship) & 0.00 \\
\hline 15 & lubuskie (Lubusz Voivodeship) & 0.00 \\
\hline 16 & zachodniopomorskie (West Pomeranian Voivodeship) & 0.00 \\
\hline
\end{tabular}

Source: own work based on [14]
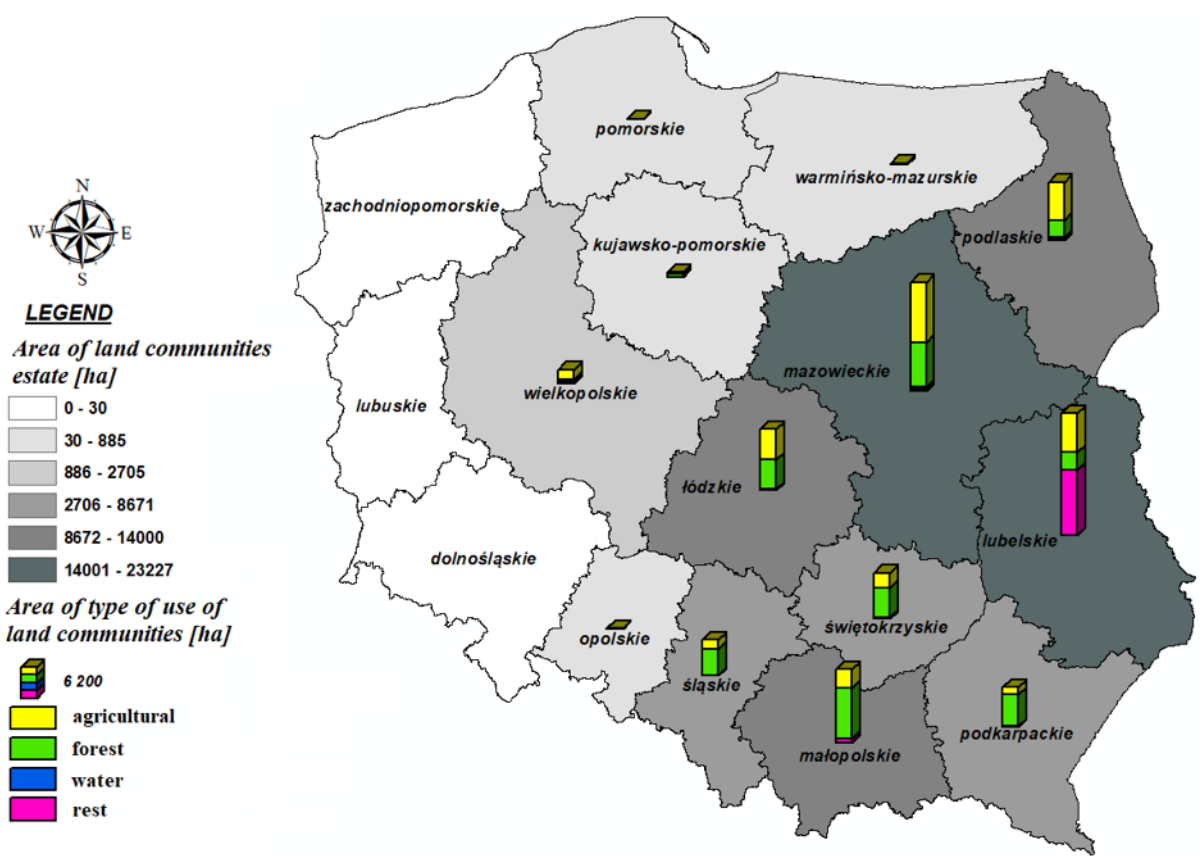

Fig. 3. Area of individual types of land communities in each from provinces in Poland Source: own work based on [14] 
Supervision over the company's activities is exercised by the competent municipality head (mayor, president of the city). The competent municipality head (mayor, president of the city) has the power to establish a compulsory company, if the eligible shareholders do not submit the company statute for approval within three months from the date of establishing the list of eligible persons. In this case, the municipality head (mayor, city president) creates a compulsory company, gives the community status and designates the company's organs.

The audit of the Supreme Audit Office in 2009 has shown that a significant part of land communities functioned unsuitably under the then applicable regulations [14]. By 2009, 21\% of land communities had formed companies and adopted the statute, while only $20 \%$ acted in accordance with the law, i.e. had the approved statute by the starosta. It should be noted that $1 \%$ of land communities were forcibly created by the municipality head (mayor, president of the city) (Fig. 4).

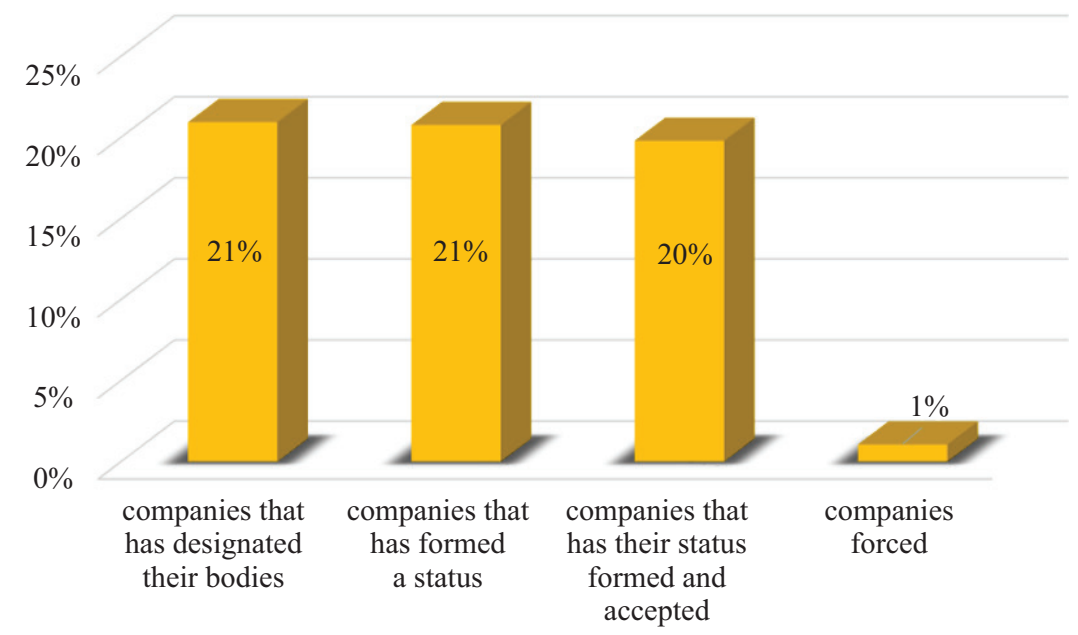

Fig. 4. The analysis of legal state of land communities until 2009

Source: own work based on [14]

Until 2009, nearly $80 \%$ of land communities had unregulated legal status. According to the Act on Real Estate Management [15], a property with an unsettled legal status means a property for which, due to the absence of a land register or a collection of documents, it is impossible to determine the people who are entitled to property rights or when the owner (perpetual usufructuary) real estate is dead and no inheritance proceedings were carried out. In the case of land communities, an unregulated legal status occurs when a list of those entitled to participate in the community or authorized entities was not established and their successors in law were not established either. 
Regulating the legal status of real estate is complicated [17, 18]. The problem of regulating the legal status of real estate in Poland concerns different properties [19-21], including ground communities [22].

Figure 5 presents the audit results of the $\mathrm{SAO}$ with the division into individual voivodeships. In the audit results of the SAO (Fig. 5), land with unregulated legal status was when a list of those entitled to participate in the community had not been established. Analyzes showed that only two voivodeships: Małopolska and Podkarpacie, had more than half of the communities acted in harmony with regulations. In the remaining 14 voivodeships, this percentage was much lower. Due to the fact that this problem occurred throughout the country after the SAO audit, legal changes regulating the operation of land communities began.

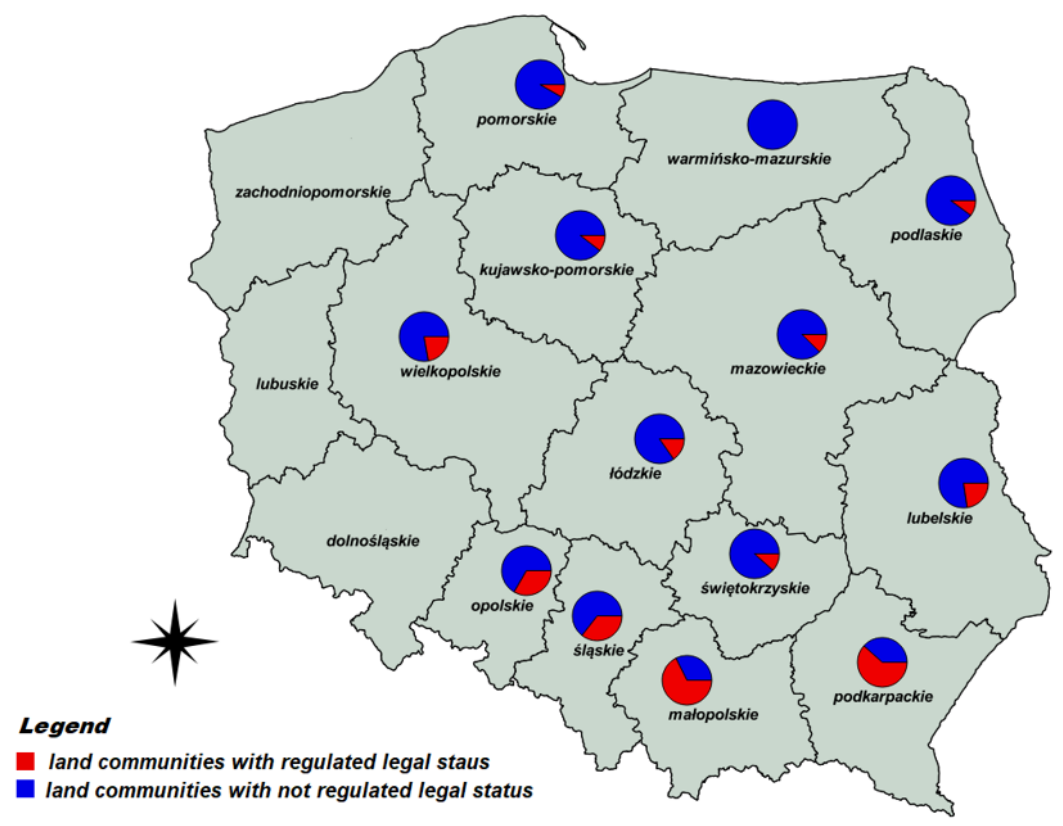

Fig. 5. Legal state of land communities in different voivodeships Source: own work based on the [14]

\section{Regulation of the Legal Status of Real Estate of Land Communities according to Current Regulations}

The amended Act on the development of land communities [13], in force since January 1, 2016, introduced the possibility of regulating the legal status of real estate of land communities by re-establishing which properties constitute land 
communities and re-establishing the list of entities entitled to participate in the land community. However, this possibility was limited in time - the application should have been submitted by the end of 2016 at the latest. The procedure for regulating the legal status of real estate of land communities according to by the amended act on communities of land is presented in Figure 6 (on the interleaf).

\subsection{Reconcile Which Properties Are Land Communities}

The initiation of administrative proceedings, the purpose of which was to determine what real estate constitutes a community of land, followed the request submitted by the relevant entity to the appropriate local starosta by December 31, 2016 at the latest. This request did not have to be submitted by all those entitled to participate in the community.

The application should have included (Article 8a (2) [13]):

- definition of real estate that constitute a community of land,

- name and surname of a natural person or a company of a legal person entitled to participate in a community of land,

- the name of the town in which the agricultural holding is entitled to participate in the land community,

- indication of the address for delivery.

The application should indicate evidence that the property is a land community. These proofs could be geodetic documents (i.e. maps, plans, lists, etc.) carried out during the establishment of the land and building register, if the land register in the area was established before July 4, 1963. Protocols were made to determine the state of ownership in which landowners were entered, in the case of land communities as landowners were entered into the inhabitants of a given village (villages, settlements, clusters).

The application should also provide evidence of meeting the conditions for the acquisition of rights to participate in the land community by the applicant (Article 8 a (3) [13]).

Those entitled to participate in the land community are (Article 6 paragraph 1 of [13]):

- natural or legal persons holding agricultural holdings if in the last year before the day of entry into force of the Act (i.e. from July 5, 1962 to July 4, 1963) they actually benefited from this community;

- if the community of land is forests, forest land or wasteland for afforestation, those entitled to participate in such a community are natural persons residing or legal persons established in the place where the community is located, or persons domiciled in in another town, and a leading agricultural holding, unless in the period of 5 years before the date of entry into force of the act, these people did not actually use the community (Article 6 (2) of [13]). 
On the basis of the application, the starosta instituted proceedings to determine which real estate constitutes a community of land. Administrative proceedings end with the starosta issuing a decision. The decision was delivered via a notice in a manner customarily adopted in a given town, displayed in a commune and county office for a period of 14 days (Article $8 b$ of [13]). After 14 days, the administrative decision is served. The decision could be appealed to the appropriate voivode through the starosta (Article 8m of [13]) within 14 days from the date of delivery, i.e. after the expiry of the time of display.

\subsection{Re-establishing the List of Entities Entitled to Participate in the Land Community}

After issuing the decision recognizing the property as community of land property, it was necessary to determine those entitled to participate in the community. According to the amended Act [13] in the first place those entitled to participate in the community are determined according to the state of the 1960s, i.e. as at 05.07.1962-04.07.1963 (the $1^{\text {st }}$ group of persons entitled). Decisions on the establishment of a list of those entitled to participate in the land community and the list of farm areas owned by them and the size of their shares in the community according to the state of the 1960s are served by the announcement in a manner customarily adopted in a given town, displayed in the commune and starosta office for a period of 14 days.

After the decision had been issued within 3 months, the community is obliged to set up a company by way of a resolution adopted by a majority of votes in the presence of at least half of those entitled. In the event that the entitled to participates in community of land does not establish the company within the required period, the municipality head (mayor, president of the city) is obliged to establish a compulsory company, give it a statute and designate the company's bodies from among those entitled to participate in the community. The municipality head (mayor, president of the city) may appoint company bodies from among persons who are not members of the company, if the persons elected or appointed to the company's authorities refuse to participate in these bodies or if the activities of these bodies will not achieve the purpose for which the company was established, in particular in the event of improper development of the land included in the community. The articles of association of the company are approved by the starosta in question.

Information on the date of submitting applications should be hung for 14 days at the poviat office, commune office and publicly disclosed in the manner customary in a given town. This information should also be published on the websites of the commune and poviat as well as in the local press. The deadline for submitting applications may not be shorter than 12 months from the date of publication of the information. The 12-month period starts from the date of posting the information on information on the possibility of submitting applications. 
Entitled to participate in the community according to the current status are II group of eligible (according to Article 6a.1):

- natural or legal persons who hold agricultural holdings and continuously for the period from January 1, 2006 to December 31, 2015 have actually benefited from the community of land or,

- natural persons who reside in a place where there is community land or keep a farm in this place - if the community of land is forests, forest land or wasteland destined for afforestation, unless for the period from January 1, 2006 until December 31, 2015, these people did not actually use the community.

After the decision on establishing the list of those entitled to participate in the land community and the list of farm areas owned by them and the size of their shares in the community as at $01.01 .2006-31.12 .2015$, the land community is also obliged to set up a company.

\subsection{Free Acquisitions of Land Property by the Municipality}

If, however, it is not possible to establish a list of those entitled to participate in the land community according to the current state (group II entitled), the starosta makes decisions about the fact that the list of eligible persons entitled to participate community of land is not established. Decisions are delivered via an advertisement in a manner customarily adopted in a given locality, displayed at the commune and county office for a period of 14 days. After issuing a decision on not establishing authorized entities to participate in the community of land, the commune may submit an application for taking over the land of the land community.

Then the starosta, within 7 days from the date on which the decision on the non-inclusion of the list of those entitled to participate in the community according to the current state (II group of eligible) became final, informs the municipality about the possibility of the free acquisition of property marked in the register of lands and buildings, as a land community together with an indication of the deadline for submitting the application. This deadline cannot be shorter than 6 months from the date of delivery of the information about the possibility of the municipality taking over the land.

The commune in the application must indicate the purpose for which it wants to acquire land. Acquisition of real estate by the commune is possible only for the purposes specified in the Act [15], i.e. for the development purposes of the commune and organized investment activities, in particular for the implementation of housing construction and related to the construction of technical infrastructure equipment, as well as for other public purposes related to the implementation of the municipality's own tasks (Article 8g (1) [13]). The voivode issues decisions on the gratuitous acquisition of the property by the commune. Acquisition of ownership takes place on the day on which the decision became final. The final decision of the voivode is the basis for entry of the ownership right in the land and mortgage register. 
In the case when the municipality in the application does not specify the purpose for which it wanted to purchase land, the voivode issues a refusal decision on the refusal of the commune to acquire property ownership. Then voivode issues a decisionon free of charge acquisition of real estate of community of land by the State Treasury. Taking over ownership of the community land by the State Treasury is also possible when the municipality did not submit the application by the statutory date. The decision of the voivode on the gratuitous acquisition by the State Treasury of the ownership of the real property is the basis for the entry of the ownership right to the land and mortgage register.

\subsection{The Possibility of Transforming the Community of Land into Co-ownership}

From 2016, i.e. since the validity of the Act amending the regulations for land communities, it has been possible to liquidate the company by adopting a resolution on transforming the community of land into co-ownership in fractional parts (the form of a notarial deed is required). It is necessary for the resolution to be adopted unanimously by all those entitled to participate in the community of land. As of the date of the adoption of mentioned resolution, the company's liquidation is opened. The resolution on transforming the land community into co-ownership forms in fractional parts the basis for making an entry in the land and mortgage register of the ownership right.

\section{Analysis of Administrative Proceedings Regarding Land Communities in Selected Counties in the Masovian Voivodeship}

The amendment to the Law on the development of land communities has made it possible to regulate the large state of affairs and counts as real estate in Poland. The procedure for regulating the correct condition of the real estate commenced on the basis of the application submitted by December 31, 2016 at the latest.

Administrative proceedings regarding terrestrial communities in selected districts of the Masovian Voivodeship were analyzed. Administrative proceedings regarding the attempts of authorized entities to participate in a community of land were analyzed. The purpose of the analyzes was to check whether the amended Act helped regulate the legal status of the land property of the land communities.

The research was carried out in the Masovian Voivodeship since the largest number of community communities are to be found in Masovia. The Masovian Voivodeship is the second in Poland in terms of the surface of real estate communities. Only $12 \%$ of land communities in this region have a regulated legal status (there are 1,573 communities in the Masovian Voivodeship, of which 196 have established 
companies). The unregulated legal status of community land was understood as the lack of established entities to participate in the community.

The research was carried out in the district of Ostrołęka and in the district of Przysucha (Fig. 7). In both districts, a large number of administrative proceedings concerning ground communities were observed.

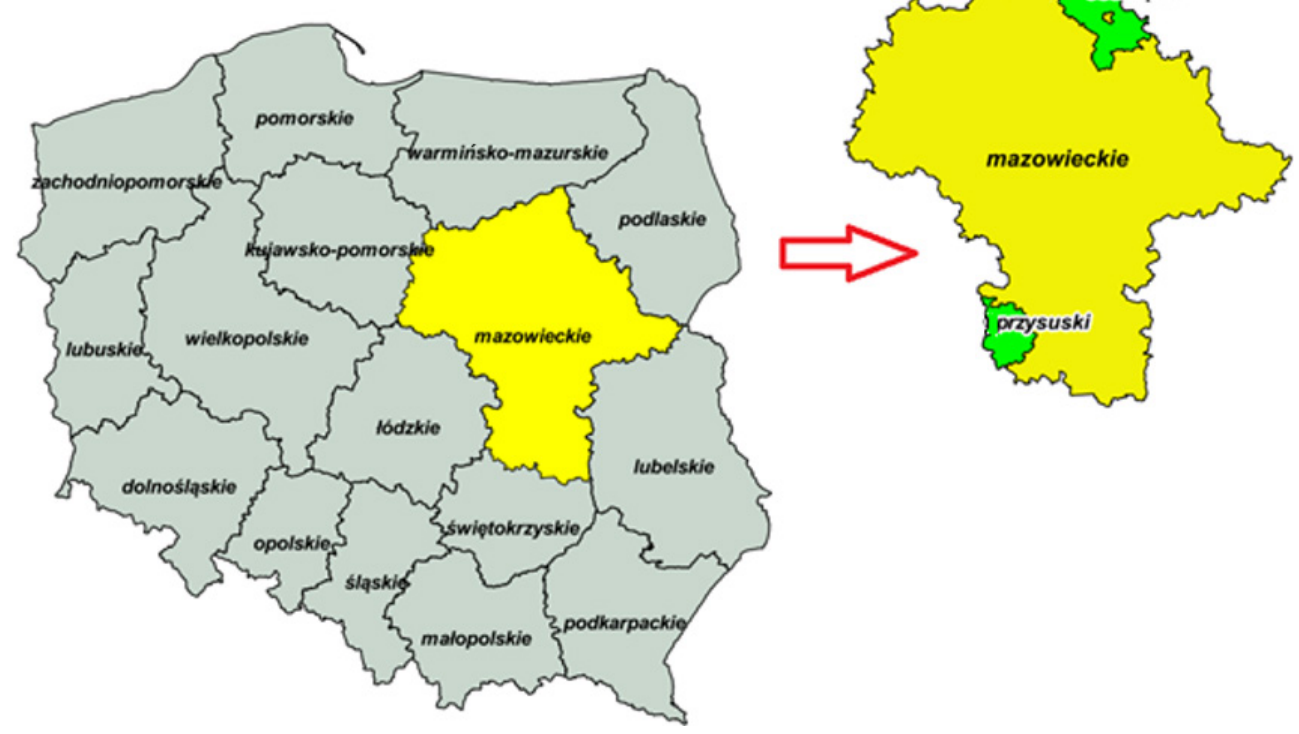

Fig. 7. Area where the research was carried out

In the area of Ostrołęa County since the amendment of the Act on the development of land communities, 20 administrative proceedings have been initiated to determine which real estate constitutes a community of land. Until November 2018, only four proceedings were completed. The rest of the proceedings remain in progress, although almost two years have passed since the applications were submitted (Fig. 8).

In accordance with the applicable provisions (i.e. according to the amended act on communities of land), after the decision on recognizing the real estate as a land community (or if such a decision was issued earlier), the starosta should also establish a list of those entitled to participate in the community. The amended Act [13] defined new rules for establishing the list of those entitled to participate in the community. According to the Act [13], the starosta, at the request of the parties submitted by December 31, 2016 at the latest, should establish a list of those entitled to participate in the community as of the 1960s, and when it is impossible, then according to the current state (2006-2015). When analyzing the administrative proceedings carried out within the Ostrołęka County, it should be noted that in none of the 
11 administrative proceedings for establishing a list of those entitled to participate in the land community it was impossible to determine those entitled to participate in the community as of the 1960s (Fig. 9).

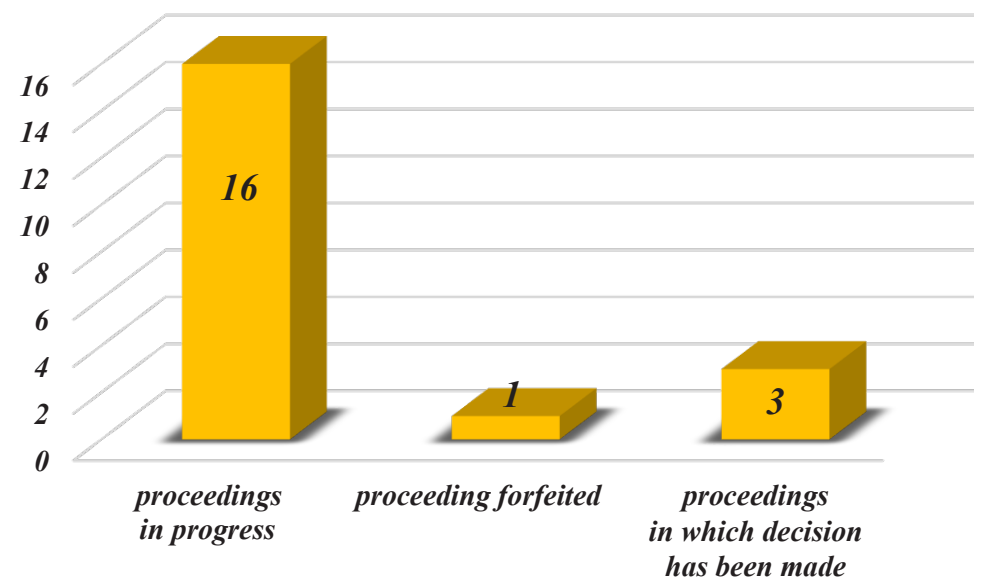

Fig. 8. Number of administrative proceedings concerning which estates constitute land communities in Ostrołęka County

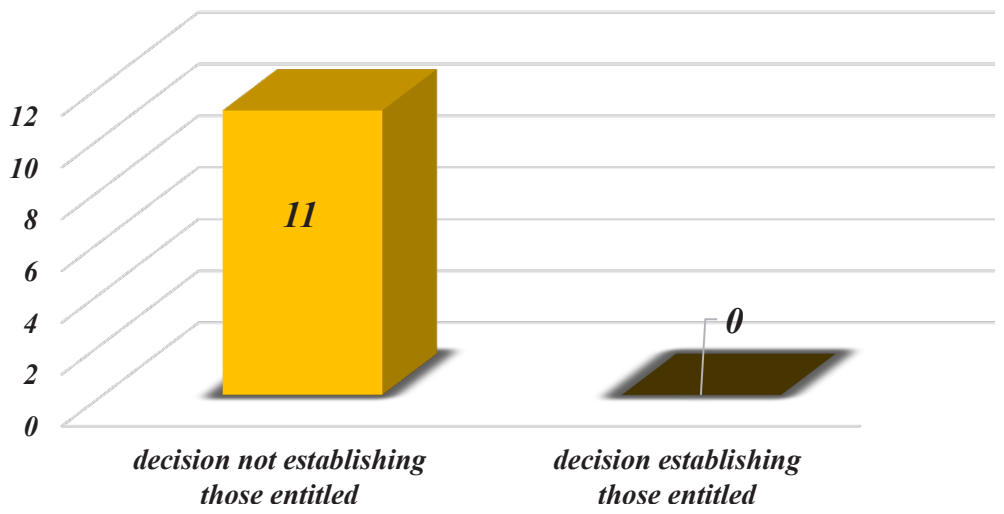

Fig. 9. Number of proceedings establishing those entitled to participate in land community according to the state from sixties in Ostrołęka County

Analyzing administrative proceedings concerning land communities conducted within the county of Przysucha, it was noticed that, as in the case of the Ostrołęa District, a large number of proceedings were instituted. 24 administrative proceedings were initiated to determine which real estate constitutes the land community. 19 administrative proceedings were instituted ex officio (due to the lack of a request from authorized parties - Article 61 (2) of the Act, the Code of Administrative 
Procedure [23]) and 5 at the request of authorized persons. 4 were completed by an administrative decision and 1 was discontinued (Fig. 10).

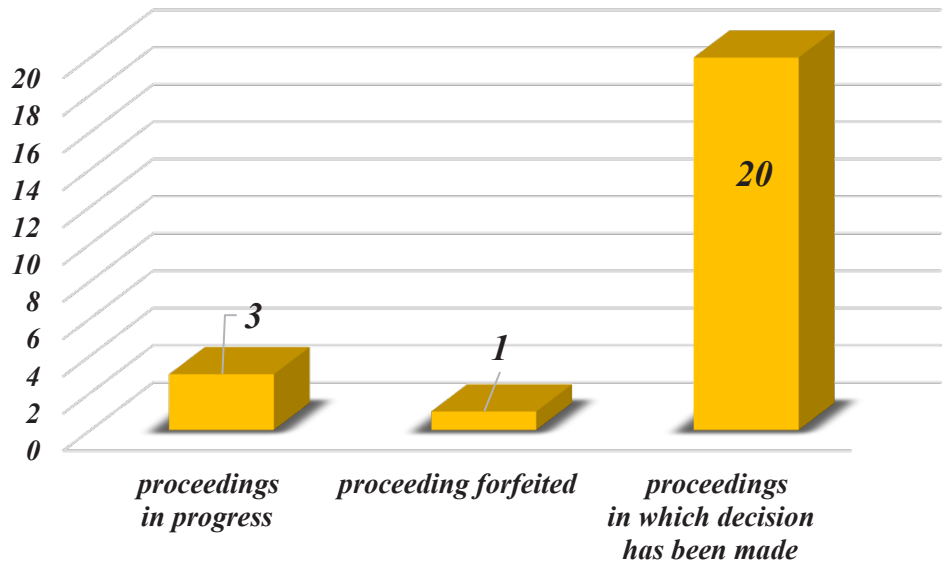

Fig. 10. Number of administrative proceedings concerning which estates constitute land community in Przysucha County

In the proceedings initiated from the office, the starosta also conducted proceedings to find out which real estate constitutes a community of land and establishing a list of those entitled to participate in the land community - which does not seem to be correct. In these procedures, the starosta issued a decision to not include a list of those entitled to participate in the community as of the 1960s without the prior decision to recognize a given property as a community of land. In the county of Przysucha, as in the case of the Ostrołęa District, it was not possible to determine those entitled to participate in the community as of the 1960s (Fig. 11).

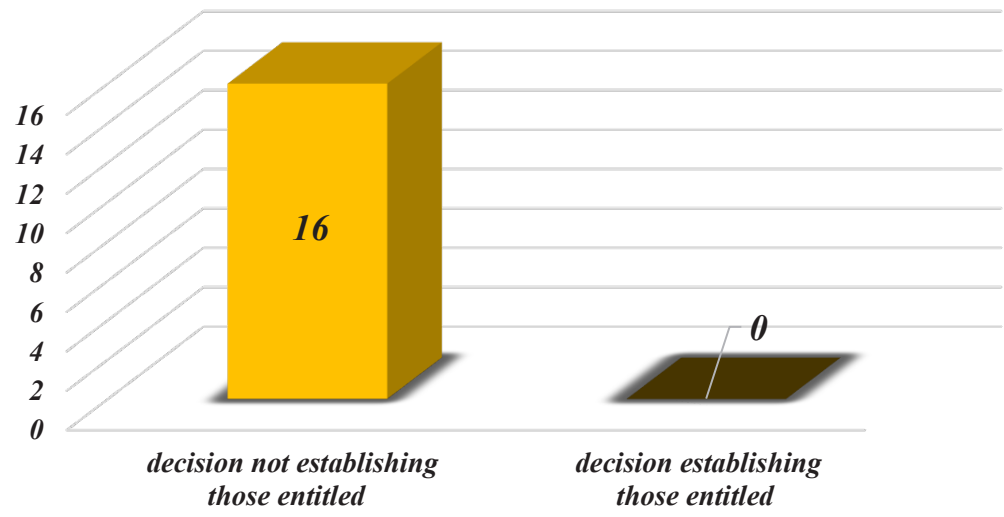

Fig. 11. Number of proceedings establishing those entitled to participate in a land community according to the state from the 1960s in Przysucha County 


\section{Conclusions}

The amendment to the Law on the development of land communities in 2015 was the result of the control of the factual and legal state of the State Treasury carried out by the Supreme Audit Office in 2009, which showed numerous irregularities in the functioning of land communities throughout Poland. The amendment to the act was aimed at facilitating the regulation of the legal status of many properties in Poland. The 2015 Act made it possible to re-determine which properties constitute land communities and to re-establish the list of entities entitled to participate in the land community. If it is impossible to determine the entities that have rights to the land community, the Act enabled the free acquisition of community land by municipalities and the State Treasury, thanks to which it gave the opportunity to regulate the legal status of many properties in a short time (the application could only be submitted until the end of 2016).

The analyzes showed that after the amendment of the Act on the development of land communities, a lot of administrative proceedings were initiated to regulate the legal status of the real estate of land communities, however, due to their complexity, the major part has not yet been completed.

The research carried out in the area of the Ostrołęka and Przysucha counties showed that in none of the administrative proceedings analyzed was it possible to determine those entitled to participate in the land community as of the 1960s. Proceedings to determine who are entitled to participate in the community according to the current state ( $2^{\text {nd }}$ group of eligible) have not yet been completed. This indicates the very complicated nature of these proceedings. In relation with however, first of all, those entitled to participate in the community should be established as at 5.07.1962-4.07.1963 ( $1^{\text {st }}$ group of persons entitled). To this purpose it should be found documents showing the condition of land from the 1960s should be reached, which is often the case it is very complicated and requires the authority to conduct the analysis of a large number of materials. Bearing in mind the large number of administrative proceedings regarding land communities, and the fact that if it is impossible to establish a list of those entitled to participate in the community (as of the 1960s and as it stands), the Community or Treasury has the right to acquire the land free of charge. It can be said that the amendment to the Act [13] gave a real opportunity to regulate the legal status of a large property in Poland in the near future.

\section{References}

[1] Stawicka E.: Wspólnoty gruntowe - aspekty cywilistyczne i administracyjnoprawne. Palestra, nr 1-2, 2008, pp. 71-91.

[2] Lipińska I.: Rola i funkcjonowanie wspólnot gruntowych we wspótczesnych warunkach gospodarczych. Zeszyty Naukowe SGGW w Warszawie - Problemy Rolnictwa Światowego, t. 10(25), z. 4, 2010, pp. 35-44. 
[3] Gołos P.: Wspólnoty gruntowe - tradycyjna forma gospodarowania lasami. Sylwan, nr 2, 2008, pp. 54-68.

[4] Jastrzębski L.: Sytuacja prawna wspólnot gruntowych w Polsce Ludowej. Państwowe Wydawnictwo Rolnicze i Leśne, Warszawa 1963.

[5] Prutis S.: Spótki do zagospodarowania wspólnot gruntowych. [in:] Stelmachowski A. (red.), Prawo rolne, LexisNexis, Warszawa 2009, p. 423.

[6] Jędrejek G.: Zarząd wspólnota gruntową. Zeszyty Prawnicze UKSW, t. 8, nr 1, 2008, pp. 151-166.

[7] Drabik L., Kubiak-Sokół A., Sobol E.: Słownik języka polskiego PWN. Wydawnictwo Naukowe PWN, Warszawa 2019.

[8] Ptaszyk M.: Spótki do zagospodarowania wspólnot gruntowych: sytuacja prawna, funkcjonowanie, perspektywy. Zeszyty Naukowe Uniwersytetu Jagiellońskiego. Prace Prawnicze, z. 129, UJ, Kraków 1989.

[9] Tönnies F.: Wspólnota i stowarzyszenie: rozprawa o komunizmie i socjalizmie jako empirycznych formach kultury. Państwowe Wydawnictwo Naukowe, Warszawa 1988.

[10] Stawicka E.: Zmiana regulacji ustawowej wspólnot gruntowych. Palestra, nr 4, 2016, s. 31-39.

[11] Puch P.: Wspólnoty gruntowe. 2010, http://www.gazetasolecka.pl/fww.html [access: October 2019].

[12] Geszprych M.: Podstawy prawne i ekonomiczno-finansowe funkcjonowania stowarzyszeń prywatnych właścicieli lasów w Polsce i wybranych krajach Unii Europejskiej - analiza porównawcza. Dokumentacja Naukowa IBL, Warszawa 2006.

[13] Ustawa z dnia 29 czerwca 1963 r. o zagospodarowaniu wspólnot gruntowych. Dz.U. 1963 nr 28, poz. 169.

[14] Informacja o wynikach kontroli aktualizacji stanu faktycznego i prawnego nieruchomości przez organy gospodarujące mieniem stanowiącym zasób nieruchomości Skarbu Państwa, gminny zasób nieruchomości i mienie gminne. Najwyższa Izba Kontroli, Warszawa 2009.

[15] Ustawa z dnia 21 sierpnia 1997 r. o gospodarce nieruchomościami. Dz.U. 2018 poz. 2204 as amended.

[16] Parzych P., Rymarczyk E., Szabat-Pręcikowska A.: Problematyka wspólnot gruntowych w aspekcie ewidencyjno-prawnym. Infrastruktura i Ekologia Terenów Wiejskich, nr 2/III, 2013, pp. 35-46.

[17] Hanus P.: Wykorzystanie dokumentacji byłego katastru austriackiego do regulacji stanu prawnego nieruchomości. Geomatics and Environmental Engineering, vol. 1, no. 4, 2007, pp. 127-138.

[18] Mączyńska A., Kwartnik-Pruc A.: Land Ownership Act as A Basis For Legal Status Regulation of Real Estate Located in Rural Areas. Infrastruktura i Ekologia Terenów Wiejskich, nr IV/1, 2017, pp. 1493-1506. 
[19] Trembecka A., Kwartnik-Pruc A.: An analysis of the changes in the structure of allotment gardens in Poland and of the process of regulating legal status. Sustainability, vol. 10, issue 11, art. no. 3829, 2018, pp. 1-20.

[20] Trembecka A.: Selected problems of regulating legal status of allotment gardens on example of city of Krakow. Geomatics and Environmental Engineering, vol. 12, no. 2, 2018, pp. 101-110.

[21] Sobolewska-Mikulska K., Cienciała A.: Problematyka geodezyjno-prawna w procesie ustalania stanu prawnego nieruchomości w Polsce. Oficyna Wydawnicza Politechniki Warszawskiej, Warszawa 2017.

[22] Szachułowicz J.: Status prawny wspólnot gruntowych. Przegląd Sądowy, nr 9, 2002, pp. 63-74.

[23] Obwieszczenie Marszałka Sejmu Rzeczypospolitej Polskiej z dnia 3 października 2018 r. w sprawie ogłoszenia jednolitego tekstu ustawy - Kodeks postępowania administracyjnego. Dz.U. 2018 poz. 2096 as amended.

\section{Analiza stanu prawnego wspólnot gruntowych}

Streszczenie: W Polsce funkcjonuje ponad 5 tysięcy wspólnot gruntowych, które posiadają nieruchomości o powierzchni powyżej 100 tysięcy hektarów. W 2009 roku Najwyższa Izba Kontroli przeprowadziła kontrolę stanu faktycznego i prawnego nieruchomości Skarbu Państwa oraz nieruchomości gminnych. Kontrola, która obejmowała również nieruchomości należące do wspólnot gruntowych, wykazała liczne nieprawidłowości w ich funkcjonowaniu na obszarze całej Polski. Skutkiem przeprowadzonej kontroli były duże zmiany ustawy regulującej działanie wspólnot gruntowych. Znowelizowana ustawa miała ułatwić regulację stanu prawnego wielu nieruchomości w Polsce.

W artykule zaprezentowano analizę stanu prawnego nieruchomości wspólnot gruntowych wykonaną na podstawie danych Najwyższej Izby Kontroli. Przedstawiono również procedurę regulacji stanu prawnego nieruchomości według przepisów znowelizowanej ustawy o zagospodarowaniu wspólnot gruntowych oraz dokonano analizy postępowań administracyjnych w wybranych powiatach celem sprawdzenia, czy znowelizowana ustawa pomogła w regulacji stanu prawnego gruntów wspólnot.

\section{Słowa}

kluczowe: wspólnoty gruntowe, regulacja stanu prawnego 


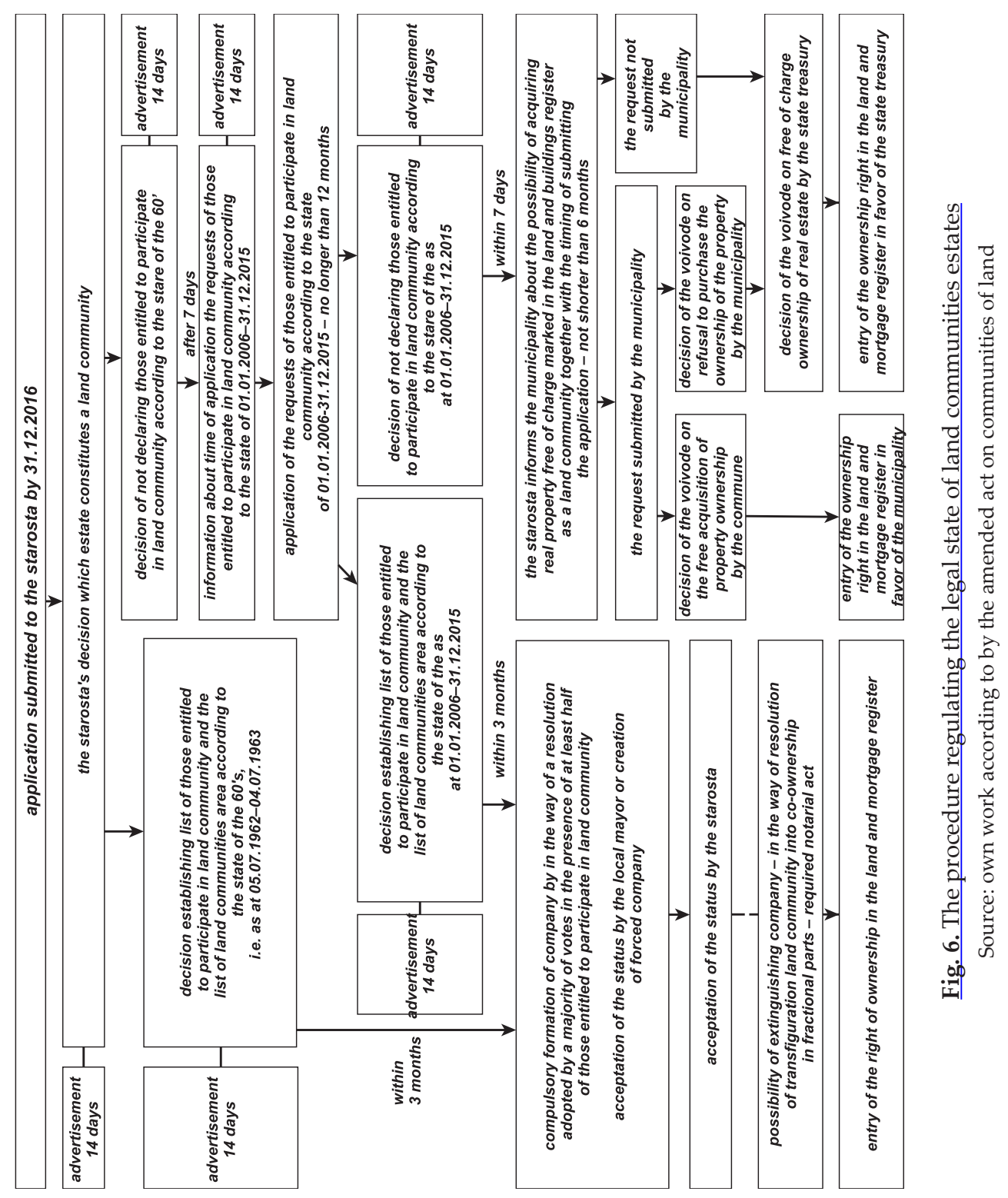

